\title{
Management Information System and Competitive Advantage
}

\author{
Afërdita Berisha-Shaqiri \\ Ph.D., Assistant Professor, Department of Management and Informatics, \\ Faculty of Economics, University of Pristina, Kosovo \\ Email: aferdita44@hotmail.com
}

\section{Doi:10.5901/mjss.2015.v6n1p204}

\begin{abstract}
We have known full of examples where the use of information technology and computer systems are seen as factors for competitive advantage. Even this paper aims to highlight how businesses provide satisfactory support and achieve competitive advantage through the management information systems. Information Management System aims to make enterprise environment as safe by providing information on competition and market. Therefore, we say that the quality of governance in an enterprise depends on the development and design of information systems based on computers that are designed according to the requirements and needs of the enterprise system. Increasing the pressure of competition forces businesses to fight for new research, new products and new markets, these businesses move can only afford having support from a quality information system. This support should enable higher quality solution for the governance of resources that businesses possess. In the last decade, information technology had a significant development. As the result, businesses have undergone a series of changes in the way of cooperation, presentation, finding buyers, suppliers, and placing products at the market. Management information systems to support management activities, this means that the structure of an information system can be classified within the hierarchy of activities, planning and management control. Activities vary according to levels of low, middle and senior management. Managers need different types of information, and the information needs determined by the decisions that must be taken. Contemporary management is increasingly dependent on information technology, because without a perfect technology and available data, the software may not have adequate information to be managers in making decisions.
\end{abstract}

Keywords: management information system, competitive advantage, business, database, decisions, information technology, enterprise, global market, digital economy, new product, new servise etc.

\section{Introduction}

Economic growth means the ability of growth of goods, products and services of a country (Miles, 2001). Using ICT also facilitates the production of goods in a short time with the help of computerized information systems, and services are quick and effective (Miles, 2001).

Management Information System is a flow of procedures for data processing based on the computer, and integrated with other procedures in order to provide information in a timely and effective manner to support decisionmaking and other management functions. The use of management information systems for more is a key factor for the production of new products and services, to collect information on activities, products produced, productivity, hiring new employees, tracking stocks etc. While earlier information systems have played a more important role in the organization and development of enterprise information systems today and new technologies and applications for them are oriented more towards the process of governance and control as the main base of manufacturing activities, purchasing, supply etc.

According to Muhamet Mustafa (1995) computing system represents subsystems connection information into a unique whole structural and conceptual aims computerization of processes in the enterprise. The information processed in the management information system of interconnecting all levels of government ranging from high-level planning and strategic placement, planning and tactical deployment, as well as planning and deployment of operational control.

The structure of the computing system according to levels of management activity is divided into: information systems and operational control; information systems knowledge bases; information systems for the control of management; information systems to support decisions; information systems strategic planning by Brian K.Williams \& Stacey C. Sawyer (2001); 


\section{What is Management Information System}

Information system is entirely related elements among themselves that function together with the purpose of collecting, processing and distribution memorizing information.

Author James O.Hicks (2003) defines information system as formalized system that collects, stores, processes and reports data from various sources to provide information needed to manage the process of making decisions. J.W.Wilkinson (1997) talking about computer operating systems mentioned five tasks or activities:

1. Data collection;

2. The processing of data;

3. Data Management;

4. Control and obtaining data and

5. Generation of information.

Through these activities by J.W.Wilkinson (1997) the data from various sources through a process called data processing is converted into information necessary for the user.

While management information systems comprise components of his own physical hardware, software, databases, procedures and personnel.

An information system is formalized system where collected and sorted out by several processes, reports, data from various sources to provide information necessary and important to obtain important management decisions. Not all information systems are organized and formalized as information sources are not other officials. Information system should be based on computer data, often collected and stored information through processing by hand (manual), although the manual information system has become more or much less important.

The purpose of an information system is processing, memorizing and transmitting appropriate information in place, and the best information system is one that performs this function with as little cost and therefore be effective efiqient.

Emphasized the importance of management information system to find the way how to manage and organize to come as soon as the result, profit is therefore the focus of the management information system (MIS) based on computer data. All systems including computer systems and computer systems consist of inputs, processes and outputs. The process of transforming inputs into outputs regards information management (management information). Processes can be subdivided into computer programs and procedures, computer programs executed by the computer hardware part, the procedures executed by humans. Inputs are raw data entering the system information (eg information from survey field) processors transform inputs into outputs (useful data for decision makers manager). Data files are booked (stored on) in an organized manner for future processing or until you need the users of the system. The staff is undoubtedly the most important component of the information system, the programmer and system analyst and also constructs and implements and maintains programs and procedures to guide the operator, though other parts of the computer which are also part of the system. Accountant, finance, marketing and personnel manuel process other aspects of computing system without actually sometimes used the computer hardware. Manager also tends to keep under control, govern, and operate a computer system. On a summary of the core (heart) of an information system is built from the inputs, processes, database and outputs. These components are executed and controlled by the hardware and personnel.

\section{Management Information System and Competitive Advantage}

In Management Information Systems by Effy Oz (2008), there are eight ways to gain competitive advantage: Reducing cost, raising barriers to market entrants, establishing high switching costs, creating new products or services, differentiating products or services, enhancing products or services, establishing alliances.

Locking in suppliers or buyers Competitive Advantage in any industry or business venture is achieved when one particular organization performs more effectively and/or efficiently than the others in the same category. This Competitive Advantage does not have to be all encompassing of the industry and may only cover small segments. A Competitive Advantage is achieved when an organization can do any one thing, process, function, etc. more effectively and or efficiently than others in that industry segment or in some cases across the entire industry.

According to the authors W.R. King, V. Grove, and E.H. Hufnagel (1989), information technology is used as a strategic tool for companies to increase their competitive advantage at a time when uncertainty is growing. The idea that information technology can contribute to the optimization of enterprise resources, enhance, enable and enhance business performance. This idea was accepted and supported by many empirical studies (V. Sethi and WR King, 1994), (Chan, SL Huff, DW Barclay, 1997), (AM Croteau and F. Bergeron, 2001).

Authors Rackoff, Wiseman, and Ullrich (1985) have identified several factors that ensure computerization of 
competitive advantage for enterprises. They are:

- Modification, differentiation or changes that make the company stand out with its products and services or weaken competition and reduce the competitive advantages;

- Adapting and adjusting supply cutting costs, reducing consumer spending and increasing competition expenses;

- Company being introduced innovative products or services that result in changes in the way business is passed then in the industry;

- Improving growth and development by increasing volume, expanding geographically and being harmonized with suppliers and customers;

- Forms of mergers and alliances through various agreements in marketing etc.

Since the business environment is constantly changing and evolving, the business itself changes all the time and with the growth and development information needs to ask businesses will vary. At the same time computing system needs to support growth, change and development. (Vakola and Wilson, 2004). The findings of the authors mentioned above clearly show that businesses invest in computing technology, because they believe that this technology will enable them to be more competitive (Malaga A. Ross, 2001).

Some other authors Urwiller and Florick (2008) noted that to create competitive difference as a result of computerization first condition are innovations in information technology, which today have become an integral part of organizational strategy and planning processes. Information Technology is not only possible, but is streamlined entity and the way to create competitive edge. To achieve competitive difference information technology and its use in business processes results in a new way of doing business (e-business) as well as providing products and services electronically. So information technology plays a crucial role in supporting the business by creating competitive advantage (Competitive Advantage), offering services and products so that customers appreciate more than the competition. This technology is able to provide operational excellence (Operational excellence), initiatives in key business branches (Major Business Initiatives) then the decision (Decision Making) and organizational transformation (Organizational Transformation). In what manner is information technology provides operational perfection (Operational Excellence) being efficient in what we do, using transaction-processing systems within the organization Transaction processing system (TPS) using Customer self-service system (CSS) to make their offer customers their transaction processing etc.

\section{Competitiv Advantage with Interorganizational Information Systems}

Many well-known examples of the use of information technology for competitive advantage involve systems that link an organization to suppliers, distribution channels, or customers. In general, these systems use information or processing capabilities in one organization to improve the performance of another or to improve relationships among organizations.

Information systems that connect two or more organizations are called inter-organizational information systems (Interorganizational Information Systems - IOS). IOS organizational operations support systems in the enterprise. One of the most popular iOS is computing system for supply chain management (Supply Chain Management-SCM). The main objective of SCM software is to increase value added in the respective industry and technology skills using information and communication technologies (ICT) and its goal is through the Internet to connect different businesses with leading factories through ICT technology applications. Information system for supply chain management (SCM) provides a complete and comprehensive project and integrates the leading factories of various businesses, facilitating and increasing management and improve the overall quality of the process flows and supply operations. SCM as integrated software also creates better relationships between customers, putting the foundations of globalization and increase the competitiveness of businesses. (Http://www.moeasmea.gov.tw). Should move out that IT and SCM software mainly used in large businesses. Research shows that these companies, most often use the concept of SCM how small. Even most of SCM software packages have been developed for large enterprise customers in terms of functionality as well as price. A cost for a small business to buy a SCM software relevant only to their specific requirements makes sense even though they may benefit from some of the generic capabilities of SCM, as the processing of orders, inventory, warehouse management and management transport etc. (www.financialexpress.com)

The system of supply chain management (Supply Chain Management Systems) enabled:

Registration of stocks and provides information about business processes between businesses, the company and between companies, and

is based on IT to support supply chain activities

It is particularly important to note that SCM as well designed system creates greater opportunities and competitive strategic and optimism helps, execution and fulfillment of activities: logistics, production, revenues, profits and expenses. 
Challenges associated with the use of this software are: top manager awareness of its importance, the close collaboration between suppliers and customers, the IT system of integrated suppliers and customers, adapting to new circumstances, ongoing IT support for SCM, and adaptation of software SCM software for enterprise resource planning (Enterprise resource-planing ERP) software for managing businesses in the areas planning, manufacturing, marketing and finance. (Stephen Haag, Maeve Cummings, Amy Phillips, 2007). In addition to the sophisticated software database also creates competitive advantage by supporting management with information. Also are important also for the functioning of the system to process transactions within an organization (Transaction Processing Systems -TPS) and customer self-serving systems (Customer Self Servicing-CSS) which seek to use the database and the database management system data (data Base Management Systems-DBMS). Data warehouses are special forms of databases which support decision making. (Stephen Haag, Maeve Cummings, Amy Phillips, 2007)

Enterprises also need to achieve competitive advantage and business intelligence. Business intelligence provides knowledge, information on the customer, competition, business partners, competitive environment, to make effective decisions, important and strategic. Acting globally businesses other than domestic competition also face foreign competition. Therefore, to compete constantly need to have in the foreground needs and desires of consumers, so that the customer is satisfied with the product, services and prices that they offer. So should:

- To achieve the highest quality of products and services offered;

- Use modern and efficient technology;

- Introduce scheme more effective management and network working;

- To acquire the best individual skills and managerial staff;

- To have access, easy access and inclusion of comprehensive information on the economics of new products and services etc. (Ljubica Lesáková, Matej Bel University, 2009)

In terms of the global economy and computer networks for businesses to survive you must increase their competitiveness in comparison with business partners and adapted to European Union standards. Therefore the businesses in the future to remain in the marketplace should definitely develop competitive strategy.

\section{Conclusion}

The classical resources are: capital, labor and raw tools. The post industrial society, information and knowledge are therefore the creation of a management information system which will create good advantage. MIS makes increasing the efficiency of activities compared with previous systems centralized where communication between subsystems has been more difficult now the basic condition for the existence and development of enterprises is well organisation, computerization and database, structuring the database for research activities and the organization of the database management needs. Important implementation of management information systems and rapid application of technical achievements as one of the most important factors of this development in enterprises and other areas is of utmost importance.

Many countries in the world are moving from the industrial economy to knowledge economy, and the growth of a country is dependent on the ability to create, accumulate and disseminate knowledge. Computer and internet are a catalyst for economic growth of knowledge by enabling people to codify knowledge in a digital form easily, and transmitted throughout the world. Advancements in information technology are a vital component of success among business. ICT has been constantly studied and used because it helps many businesses to expand and compete with competitors. Using ICT to enhance the impact and effectiveness processes to support business decisions and cooperation in the group. A successful case is that companies use this technology are creating entirely new business and advantage.

Businesses that still do not use technology or use ICT to reduce the mass will have problems to survive in the global market. In addition, businesses that are not adapted to the fast pace and complexity of the business will lose from growing globalization and competition.

Economic development we see today refers to the days of social progress and especially technological. This implies in particular the change in the production of goods and services, rather than simply an increase in production is not achieved using old methods of production on a larger scale.

\section{References}

Miles,P. Globalisation - Economic Growth and Development and Development Indicators. Planet Papers. 2001.

Muhamet Mustafa, Kibernetikë dhe hyrjë ne informatik, Prishtinë, 1995, p.229. 
Brian K.Williams \& Stacey C. Sawyer "Using information Technology"- Fourth Edition, McGraw-Hill.2001, p.417.

Hicks,Jr, O.James, Management Information System, 2003, (Third edition, Virginia Polytechnic Institute and State University).

J.W.Wilkinson, Accounting Information Systems - Essential Concepts \& Application, 1997

W.R. King, V. Grove, and E.H. Hufnagel, "Using Information and Information Technology for Sustainable Competitive Advantage: Some Empirical Evidence," Information \& Management, vol. 27, nr. 2, 1989, fq. 87-93.

Effy Oz, Management Information Systems, Sixth Edition Hardcover - January 23, 2008

V. Sethi and W.R. King, "Development of Measures to Assess the Extent to which an Information Technology Application Provides Competitive Advantage," Management Science, vol. 40, no. 12, 1994, fq. 1601-1627. [15] Y.E.

Chan, S.L. Huff, D.W. Barclay, and D.C. Copeland, "Business Strategic Orientation, Information Systems Strategic Orientation, and Strategic Alignment," Information Systems Research, vol. 8, nr. 2, 1997, fq. 125-150.

A.M. Croteau and F. Bergeron, "An Information Technology Trilogy: Business Strategy, Technological Deployment, and Organizational Performance," J. of Strategic Information Systems, vol. 10, 2001, fq. 77-99.

N.Rackoff, C.Wiseman, dhe W.A. Ullrich, Information Systems for Competitive Adventage : Implementation of a Planing Procrss", MIS Quarterly (December 1985), 285-94.

Vakola, M. \& Wilson, I.E. The challenge of virtual organization: critical success factors in dealing with constant change. Team Performance Management, 10 (5/6),2004, fq.112-120.

Ross A. Malaga, Information systems technology, University of Maryland , 2001

Robert Urwiler, Mark N. Frolick. The IT Value Hierarchy:Using Mslows,s Hierarchy of needs as a metaphor for gauging the maturity level of Information Technology use withing competitive organizations, 2008 (Information Systems Management, 25: 93-97)

Johnston, H. Russell; Vitale, Michael A., Creating Competitive Advantage With Interorganizational Information Systems, 1998 http://www.moeasmea.gov.tw/ct.asp?xltem=2688\&ctNode=353\&mp=2\#top,visit: 9.11.2009.

http://www.financialexpress.com/news/why-supply-chain-management-is-imperative-for-smes/201102/3, 2007, visit, 9.11.2009

Stephen Haag, Maeve Cummings, Amy Phillips: Management Information systems for the information age. 2007, McGraw-Hill Irwin. p.24.

L'ubica Lesáková, Matej Bel University, Faculty of Economics, Tajovského 10, 97590 Banská Bystrica, Slovak Republic,2009, http://kgk.bmf.hu/system/files/Lesakova.pdf. 